\title{
Corruption and Foreign Direct Investment: Empirical Investigation of Asian Developing Economies
}

\author{
Mahnaz Muhammad Ali ${ }^{1}$, Mariam Abbas Soharwardi ${ }^{2}$, Rozina Sadiq ${ }^{3}$ \\ ${ }^{1}$ Assistant Professor, Department of Economics, The Islamia University of Bahawalpur, Pakistan \\ ${ }^{2}$ Lecturer, Department of Economics, The Islamia University of Bahawalpur, Pakistan \\ ${ }^{3}$ The Islamia University of Bahawalpur, Pakistan
}

\section{A B S T R A C T}

Developing economies have different cultural and economic characteristics, but they often experience similar levels of corruption. At one side developing economies are facing the issue of corruption; on the other hand, they are a potential recipient of FDI. The present study used the data of 31 developing Asian economies from 2000 to 2017 to determine the impact of host country's level of corruption on inward FDI. System GMM technique is applied for empirical investigation since the problem of endogeneity and heteroscedasticity are found in the models. Results reveal that corruption has a positive and statistically significant impact on inward FDI; corruption also has a positive impact on FDI inflows to GDP ratio for the panel countries. Hence the results of the study endorse the grease the wheel hypothesis of corruption. It is concluded countries should focus their resources to create business friendly environment instead to focus on anti-corruption policies only.

Key words: Corruption, FDI inflows, Asian Developing Economies, System GMM

\section{INTRODUCTION}

In the last decade, corruption has materialized as one of the important determinant of FDI inflows. Corruption is an institutional factor that affects domestic investment and economic growth in developing countries (Mauro, 1995) and also has impact on inward FDI. Corruption which refers to the misuse of public power for personal benefit, mainly occurs where the public and the private sectors work together. Probability of corruption increases where public sector officers directly deal with the private sector and they have discretion over public resources (Rose-Ackerman, 1997). There exists mixed evidence about the impact of corruption on FDI inflows. Corruption 
can be helping hand or deterrence for foreign direct investment (Hines, 1995; Wei, 2000). The grabbing hand view of corruption argues that corruption is deterrence to FDI (Fisman \& Svensson, 2007; Hines, 1995; Judge, McNatt, \& Xu, 2011; Navickas, Navickas, \& Kordoš, 2016; Wei 2000). They argued that corruption could discourage inward FDI in different ways. On the contrary, it is believed that corruption is an essential evil; a lubricant to speed up the complex process. The helping hand view of corruption argues that corruption can act as grease money that can benefit the foreign investor in many ways (Bellos \& Subasat, 2012; Omodero, 2019). Whether corruption is harmful or not for FDI inflows is a significant empirical matter. Corruption is the phenomenon of the developing world and developing countries are relying on capital inflows in the form of FDI and received most significant FDI inflows. So it becomes crucial to empirically investigate the impact of the level of perceived corruption on FDI inflows in developing Asian Economies, because so far the available literature did not address the issue of impact of corruption on inward FDI in developing Asian economies. Existing literature suggested mixed evidence about the impact of corruption on inward FDI.

\section{LITERATURE REVIEW}

\subsection{Review of Literature on Sand the Wheel View of Corruption}

The difference in the corruption level between the host and home country can also affect the FDI flows. Using the panel of developed, developing and transitional economies it was found that greater the corruption level differential between home and host country, lesser would be FDI from home to host country (Habib \& Zurawicki, 2002). The choice of foreign investor for joint venture or for sole ownership was strongly affected by the level of corruption in recipient country and technological sophistication of the foreign investors. Using firm level data it was explored that US-based foreign investors were more hesitant to invest in a joint venture in more corrupt countries (Smarzynska \& Wei 2000). Corruption can also affect the flow of other forms of capital inflows like portfolio investment and foreign loans. Wei and Wu (2002) proved that capital flows tilt from FDI to bank lending in more corrupt countries for the sample of 
103 countries. Contrary to corruption, more transparent countries can attract more FDI. Increase in transparency raking of a country by one point can increase the inward FDI by 40\% (Drabek \& Payne, 2002). Transparency and corruption in host countries are considered as political and cultural determinant of FDI inflows respectively. Zhao, Kim and Du 2003 explored for the panel of 40 countries and concluded that more corruption and low level of transparency reduce the FDI. Similarly Voyer and Beamish (2004) investigated the issues of Japanese foreign investors. It was hypothesized that the high level of perceived corruption in the host country would lead to a low level of investment by Japanese companies. The data of 29546 companies investing in 59 industrial and emerging economies was used to test the hypothesis. The results concluded that corruption in the host country negatively affects the FDI by Japanese companies, especially in emerging countries.

Market attractiveness encourages the FDI and corruption discourages the FDI. Attractiveness of market can reduce the magnitude of negative influence of corruption (Brouthers, Goa \& McNicol, 2008; Quazi, 2014; Quazi, Vemuri \& Soliman, 2014) explored less corruption greater political stability, larger market size, higher investment return, Govt. effectiveness, economic freedom, trade liberalization, better infrastructure and improvement in human capital boost the volume of inward FDI for the region South Asia and East Asia and for the group of 53 African countries respectively.

Maximum of the available studies on sand the wheel view of corruption used panel data analysis and panels were specified as developed countries, developing countries, transitional countries, OECD and non OECD countries, Latin American countries, Asian economies, African economies and European countries (Alemu, 2012; Azam \& Ahmad, 2013; Egger \& Winner, 2006; Godlinez \& Liu, 2015; Habib \& Zurawicki, 2002; Pajunen, 2008; Quazi, 2014; Quazi et al., 2014; Al-Sadig, 2009; Wah, 2009). Only few studies were found that used firm/company level data (Hakkala et al., 2008; Smarzynska \& Wei, 2000; Voyer et al., 2004). A large number of studies used corruption perception index CPI by transparency international as measure of corruption (Egger \& Winner, 2006; Habib \& Zurawicki, 2002; Hakkala et al., 2008; Ohlsson, 2007; Quazi, 2014; Quazi et al., 2014; Udenze, 2014; Wei \& Wu, 2002; Zhao et al., 2003) 
because CPI covered data on large number of countries hence the present research also used CPI as measure of corruption. Most of the studies used OLS (Bayraktar, 2015; Drebek \& Payne, 2002; Habib \& Zurawicki, 2002; Hakkala et al., 2008; Sadig, 2009; Udenze, 2014; Wah, 2009; Zhao et al., 2003) and fixed effect model (Azam \& Ahmad, 2013; Egger \& Winner, 2006; Godlinez \& Liu, 2015; Al-Sadig, 2009; Wei \& Wu, 2002) for empirical analysis.

\subsection{Review of Literature on Grease the Wheel View of Corruption}

Most of the work done in the area of corruption and FDI established corruption as deterrence for FDI inflows as discussed in the first section of the review of literature. However, there is some empirical work which demonstrated the helping hand hypothesis of corruption that indicates that corruption plays a decisive role to invite inward FDI.

A study by Egger and Winner (2005) endorsed the helping hand hypothesis of corruption. A group of 73 countries including developed and less developed countries for the period of 1995-1999 were investigated empirically using fixed effect model. The findings confirmed the short term and long run positive influence of corruption on FDI stock. The outcome of the study had endorsed that corruption can grease the wheel for inward FDI.

Similar to Egger and Winner (2005), Barassi and Zhou (2012) supported grease the wheel view of corruption by using the parametric and non-parametric approach of analysis. Using fixed effect and panel probit models study revealed that influence of corruption on FDI stock is not homogenous for the panel of OECD and developed countries. Results of the parametric method demonstrated that higher level of corruption was a hindrance for incoming FDI, however once the country has selected as a host country than high level of corruption is not deterrence for FDI inflows.

Another study by Xu, Zhang and Yano (2017) used the firm-level data of 12400 firms from 120 cities of China. It was concluded that corruption money could reduce red tapism and increased the chances of preferential treatment in obtaining the resources and licensing etc. Corruption can affect inward FDI differently in different countries. In contrast to above stated studies, Ardiyanto (2012) found mixed evidence on the impact of corruption on inward FDI. Study used the panel of 82 developed and developing 
countries for the years 1996-2010 to find out the impact of corruption on inward FDI using simple OLS and Generalized Least Square GLS. Results of the study established that corruption played a role to sand the wheel for FDI in case of developed countries. However, corruption encouraged the FDI by greasing the wheel of the complex and slow bureaucratic processes in developing countries.

Similarly, Ravi (2015) identified different impact of corruption on FDI in India and China using descriptive analysis. Study found any mega corruption scandal could severely discouraged FDI inflows. Contrarily giving and receiving the gift is an everyday norm in Chins which indirectly encourage the corruption level in China.

All the studies on helping hand hypothesis had used the panel date set and most of the studies used the fixed effect model for empirical investigation.

\subsection{Conceptual Framework}

There is not a single definition of corruption. Different people define corruption differently. The definition often used by social scientists is "the abuse of public office for private gain" Nye (1967).

Corruption can grease the wheel of the economy (Lui, 1985; Beck \& Maher, 1986; Bjorvatn \& Soreide, 2005; and Saha 2003). Corruption can also increase the returns of FDI and can increase economic efficiency. First of all, by bribing government officials' foreign investor can speed up the bureaucratic paper work and can get permits and license without unnecessary delays (Leff, 1964; Leys, 1965; Huntington, 1968; Lui, 1985). Second, they can avoid government regulations; for example, they can skip inspections. Third, they can reduce the risk of government predatory behavior and get the benefit of low tax or can avoid taxes (Cai, Fang, \& Xu, 2011; Hellman, Jones, \& Kaufman, 2003). Fourth, foreign investors can get public funds or access to publically funded projects (Tanzi \& Davoodi, 2000). Fifth, in some cases foreign investors even can charge over the price for public services. Helping hand theory of corruption is empirically supported by Egger and Winner, 2005; Barrasi and Zhou, 2011; Ardiyanto, 2012; Petrou and Thanos, 2014; Ravi, 2015; Kolnes, 2016 and Xu et al., 2017. Given the above discussion, a theoretical framework for helping hand theory of corruption can be formulated as under. 


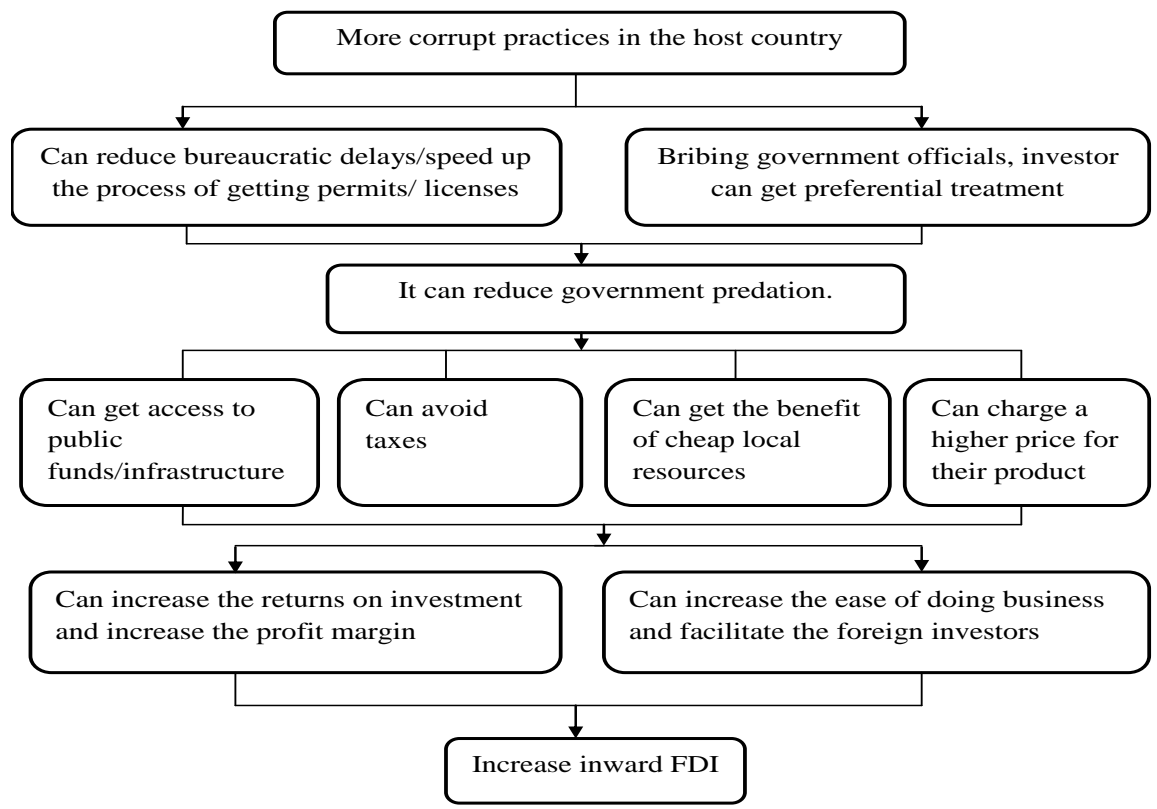

Figure 1. Positive Impact of Corruption on Inward FDI

There are some other determinants of FDI discussed in literature. Theoretical linkages among corruption, FDI and other control variables can be explained through the following flow chart.

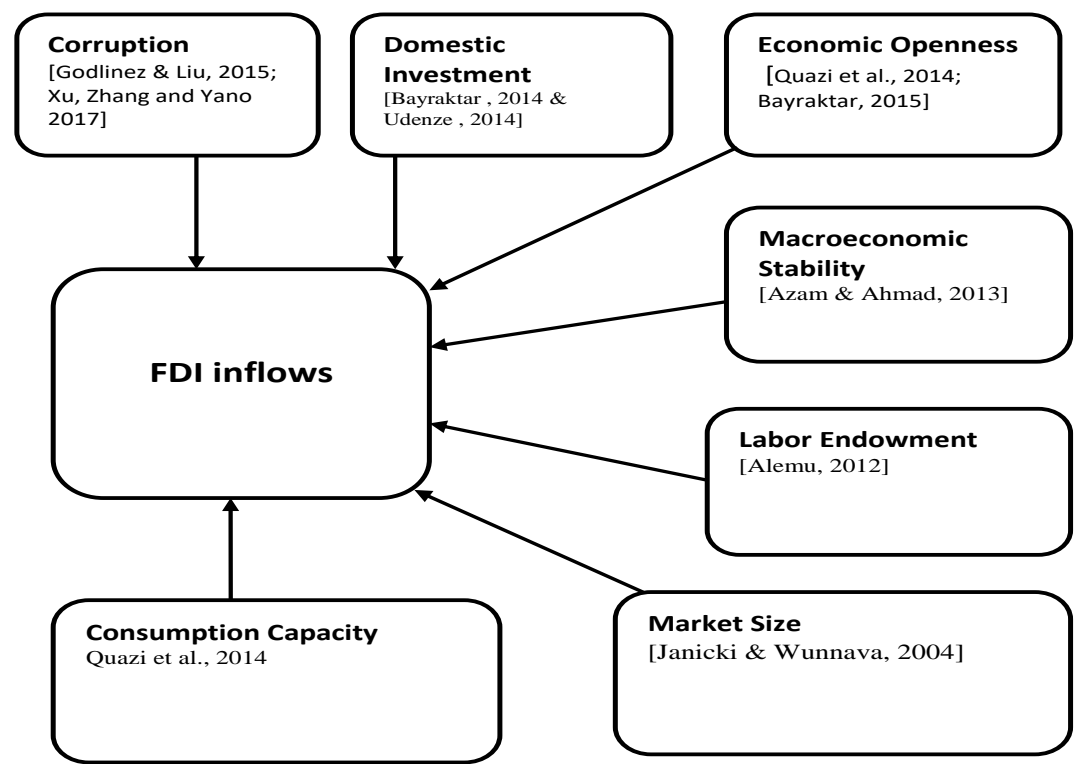

Figure 2. Theoretical Framework for Model Specification 
Based on the above stated theoretical linkages, the functional form of the model can be written as

FDI $=$ fLagged Value of FDI, Corruption, Domestic Investment

Economic Openness, Inflation, Labor Endowment,

Size of the Economy, Consumption Capacity

\subsection{Variable Description}

\begin{tabular}{|c|c|c|c|}
\hline Variable & Measurement & Data source & Expected Sign \\
\hline \multicolumn{4}{|c|}{ Dependent Variable } \\
\hline FDI & Measured as inflows & UNCTAD & \\
\hline \multicolumn{4}{|c|}{ Principal Variable } \\
\hline Corruption & $\begin{array}{l}\text { Corruption Perception Index } \\
\text { country score subtracted from } 100\end{array}$ & $\begin{array}{l}\text { Transparency } \\
\text { International }\end{array}$ & $+/-$ ve \\
\hline \multicolumn{4}{|c|}{ Control Variables } \\
\hline $\begin{array}{c}\text { Domestic } \\
\text { Investment }\end{array}$ & $\begin{array}{l}\text { Gross Fixed Capital Formation used } \\
\text { as proxy for domestic investment }\end{array}$ & WDI & +ve \\
\hline $\begin{array}{l}\text { Economic } \\
\text { Openness }\end{array}$ & Measured by trade openness & UNCTAD & + ve \\
\hline $\begin{array}{c}\text { Consumption } \\
\text { Capacity }\end{array}$ & Measured by GDP per Capita & UNCTAD & $+\mathrm{ve}$ \\
\hline Market Size & Total population of the country & UNCTAD & $+\mathrm{ve}$ \\
\hline $\begin{array}{l}\text { Macroeconomic } \\
\text { stability }\end{array}$ & $\begin{array}{l}\text { Measured by Consumer Price Index } \\
\text { in } 2005 \text { Base year }\end{array}$ & UNCTAD & -ve \\
\hline $\begin{array}{c}\text { Labor } \\
\text { Endowment }\end{array}$ & Unemployment rate & WDI & + ve \\
\hline
\end{tabular}

\section{RESEARCH METHODOLOGY}

\subsection{Model Specification}

After the detailed description of study variables the econometric specification of the model can be written as under.

\subsection{Model.}

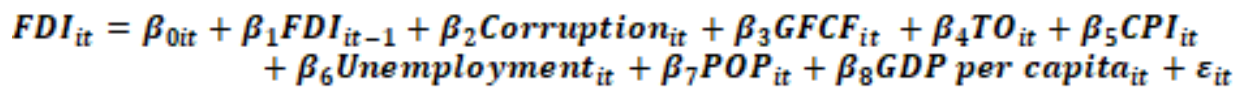

$\beta o=$ intercept, $\beta 1$ to $\beta 8$ coefficients indicate change in FDI due to change in corruption, GFCF, TO, CPI, Unemployment, POP and GDP per capita respectively. $\varepsilon$ indicates error term, $\mathrm{t}=2000-2017$ and $\mathrm{i}=31$ countries. 


\subsection{Estimation Technique}

For the present study system GMM technique is used for empirical investigation. Lagged value of FDI is considered as one of the vital determinants of FDI inflows. As, the model included lagged value of dependent variable as control variable, so system GMM is considered as more suitable technique. Since, it can handle the issue of endogeniety more appropriately. Further number of cross sections is greater than the number of time series. Dollar and Kraay (2004) claimed that panel data methodologies other than system GMM are not suitable to incorporate cross country differences in the panel. Difference GMM also cannot incorporate geographical and other time invariant country specific characteristics. The System GMM estimator proposed by Arellano and Bover (1995) and Blundell and Bond (1998) combines the standard set of moment conditions in first differences with lagged levels as instruments, with an additional set of moment conditions derived from the equation in levels. The econometric specification for the model can be written as.

$L F D I_{\text {it }}=\beta_{o}+\beta_{1} L F D I_{\text {it }-1}+\beta_{2}\left(\right.$ Corruption $\left._{i t}\right)+\beta_{3}\left(L G F C F_{i t}\right)+\beta_{4}\left(T O_{i t}\right)+$ $\beta_{5}\left(C P I_{i t}\right)+\beta_{6}\left(\right.$ Unemployment $\left._{i t}\right)+\beta_{7}\left(L P O P_{\text {it }}\right)+\beta_{8}\left(\right.$ Per Capita GDP $\left.P_{\text {it }}\right)$ $+\varepsilon_{\text {it }}$

Difference form

$\Delta L F D I_{\text {it }}=\alpha_{1} \Delta L F D I_{\text {it }-1}+\alpha_{2} \Delta\left(\right.$ Corruption it $\left._{\text {it }}\right)+\alpha_{3} \Delta\left(L G F C F_{\text {it }}\right)+\alpha_{4} \Delta\left(T O_{\text {it }}\right)+$

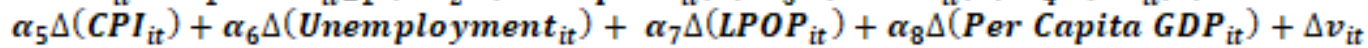

\section{RESULTS AND DISCUSSION}

\begin{tabular}{|c|c|c|c|c|}
\hline \multicolumn{5}{|c|}{$\begin{array}{l}\text { Table 1. Impact of Corruption on FDI Inflows: Panel of Developing A } \\
\text { Economies } \\
\text { Dynamic Panel-Data Estimation Using System GMM }\end{array}$} \\
\hline \multirow[t]{2}{*}{ VARIABLES } & \multicolumn{4}{|c|}{ Dependent Variable: Log of FDI Inflow } \\
\hline & 1 & 2 & 3 & 4 \\
\hline \multirow{3}{*}{ LFDI $_{t-1}$} & $.8045771 * * *$ & $.6695271 * * *$ & $.56913 * * *$ & $.4861481 * * *$ \\
\hline & [14.46] & [6.69] & {$[5.45]$} & [4.13] \\
\hline & 0.000 & 0.000 & 0.000 & 0.000 \\
\hline \multirow{3}{*}{ Corruption } & $.0206447 * *$ & $.044942 * * *$ & $.0373123 * *$ & $.0506361 * * *$ \\
\hline & [2.11] & [2.61] & [2.25] & {$[2.70]$} \\
\hline & 0.034 & 0.009 & 0.025 & 0.007 \\
\hline LGFCF & $.0541365 * *$ & $.0920445^{* * *}$ & $.0834996 * * *$ & $.110151 * * *$ \\
\hline
\end{tabular}




\begin{tabular}{|c|c|c|c|c|}
\hline & {$[2.36]$} & {$[3.42]$} & {$[3.26]$} & {$[3.49]$} \\
\cline { 2 - 5 } & 0.018 & 0.001 & 0.001 & 0.000 \\
\hline \multirow{4}{*}{ TO } & $.0126646^{* * *}$ & $.0151295^{* *}$ & $.0124778^{* *}$ & $.0133403^{* *}$ \\
\cline { 2 - 5 } & {$[3.86]$} & {$[2.34]$} & {$[2.01]$} & {$[2.23]$} \\
\cline { 2 - 5 } & 0.000 & 0.019 & 0.044 & 0.026 \\
\hline \multirow{3}{*}{ LPOP Per } & $.1074507^{* *}$ & $.2342514^{*}$ & $.351897^{* * *}$ & $.438476^{* * *}$ \\
\cline { 2 - 5 } & {$[2.03]$} & {$[1.82]$} & {$[2.66]$} & {$[3.08]$} \\
\cline { 2 - 5 } Capita GDP & 0.042 & 0.069 & 0.008 & 0.002 \\
\hline \multirow{3}{*}{ Inflation CPI } & & $.2911709^{*}$ & $.4651606^{* * *}$ & $.4610529^{* * *}$ \\
\cline { 2 - 5 } & & {$[1.79]$} & {$[2.71]$} & {$[2.80]$} \\
\cline { 2 - 5 } & & 0.073 & 0.007 & 0.005 \\
\hline \multirow{3}{*}{ Unemployment } & & & $-.006148^{* *}$ & $-.008131^{* * *}$ \\
\cline { 2 - 5 } & & & {$[-2.23]$} & {$[-2.69]$} \\
\cline { 2 - 5 } & & & 0.026 & 0.007 \\
\hline \multirow{3}{*}{ Constant } & $-4.61141^{* * *}$ & $-11.3374 * * *$ & $-12.9095^{* * *}$ & $-14.4320 * * *$ \\
\cline { 2 - 5 } & {$[-3.78]$} & {$[-3.60]$} & {$[-4.23]$} & {$[-4.60]$} \\
\cline { 2 - 5 } & 0.000 & 0.000 & 0.000 & 0.000 \\
\hline AR2P-value & 0.000 & 0.000 & 0.000 & 0.000 \\
\hline Sargan P-value & 0.478 & 0.841 & 0.703 & 0.546 \\
\hline
\end{tabular}

[] shows z-values and shows p-values

$* * * 1 \%$ level of significance, $* * 5 \%$ level of significance, $* 10 \%$ level of significance

\begin{tabular}{|c|c|c|c|c|}
\hline \multicolumn{5}{|c|}{$\begin{array}{l}\text { Table 2. Impact of Corruption on FDI Inflows to GDP Ratio: Panel of Developing } \\
\text { Asian Economies } \\
\text { Dynamic Panel-Data Estimation Using System GMM }\end{array}$} \\
\hline \multirow{2}{*}{ VARIABLES } & \multicolumn{4}{|c|}{ Dependent Variable: FDI inflow to GDP ratio } \\
\hline & 1 & 2 & 3 & 4 \\
\hline \multirow{3}{*}{$\mathrm{LFDI}_{\mathrm{t}-1}$} & $.5048196^{* * * *}$ & $.6438938 * * *$ & $.6427274 * * *$ & $.4794006^{* * * *}$ \\
\hline & [4.96] & [7.50] & [7.88] & [9.73] \\
\hline & 0.000 & 0.000 & 0.000 & 0.000 \\
\hline \multirow{3}{*}{ Corruption } & $.0008165 *$ & $.0015348 *$ & $.0010162 *$ & $.0009788^{* *}$ \\
\hline & [1.70] & [1.81] & [1.95] & [2.43] \\
\hline & 0.090 & 0.070 & 0.051 & 0.015 \\
\hline \multirow{3}{*}{ LGFCF } & $.0027524 *$ & .0009578 & $.0020965^{* *}$ & $.0021448^{* * * *}$ \\
\hline & [1.79] & {$[0.80]$} & [2.06] & [2.57] \\
\hline & 0.074 & 0.421 & 0.040 & 0.010 \\
\hline
\end{tabular}




\begin{tabular}{|c|c|c|c|c|}
\hline \multirow{3}{*}{$\mathrm{TO}$} & $.0005847 * * *$ & $.0004981 * * *$ & $.0005453 * * *$ & $.0006399 * * *$ \\
\hline & [2.94] & [2.73] & [5.36] & [6.90] \\
\hline & 0.003 & 0.006 & 0.000 & 0.000 \\
\hline \multirow{3}{*}{ CPI } & & $-.0004247 * *$ & $-8.38 \mathrm{e}-06$ & -.000082 \\
\hline & & {$[-2.56]$} & {$[-0.12]$} & {$[-1.46]$} \\
\hline & & 0.011 & 0.904 & 0.144 \\
\hline \multirow{3}{*}{ LPOP } & & & .0024239 & $.0038893 *$ \\
\hline & & & [1.03] & [1.95] \\
\hline & & & 0.304 & 0.051 \\
\hline \multirow{3}{*}{$\begin{array}{c}\text { LOG Per } \\
\text { Capita GDP }\end{array}$} & & & & $.0083111 * * *$ \\
\hline & & & & [2.77] \\
\hline & & & & 0.006 \\
\hline \multirow{3}{*}{ Constant } & $-.1401295 * *$ & -.0994736 & $-.1774062 * * *$ & $-.2708052 * * *$ \\
\hline & {$[-2.13]$} & {$[-1.12]$} & {$[-3.77]$} & {$[-6.98]$} \\
\hline & 0.034 & 0.264 & 0.000 & 0.000 \\
\hline AR2P-value & 0.660 & 0.312 & 0.375 & 0.561 \\
\hline $\begin{array}{l}\text { Sargan P- } \\
\text { value }\end{array}$ & 0.965 & 0.224 & 0.129 & 0.116 \\
\hline
\end{tabular}

[ ] shows z-values and shows p-values

$* * * 1 \%$ level of significance, $* * 5 \%$ level of significance, $* 10 \%$ level of significance

Per capita GDP is an indicator of consumption capacity of the host economy. High per capita income indicates good health and education conditions in the economy. Results are consistent with the results of Bayraktar 2014, Azam and Ahmad 2013, Ardiyanto 2012, Barassi and Zhou 2011. Unemployment in the host economy is used as an indicator of labor availability. This coefficient is expected to have a positive impact on inward FDI. However, in the present model, the coefficient of unemployment is insignificant. Results are in contrast with the findings of Godlinez and Liu 2015, and Habib and Zurawicki 2002.

In the second model, the same explanatory variables (used in the first model) are regressed taking FDI inflows to GDP ratio as the dependent variable. Since panel countries have different size of the economy therefore FDI to GDP ratio is important measure of FDI inflows relative to size of the economy. Results are reported in table 02 and all the results are almost similar to the first model except some coefficients which are not significant in the second model. Similar to the first model corruption coefficients 
have a positive sign and it is significant in all specifications. GFCF has a positive sign, but its coefficient is insignificant in one specification. Trade openness has a positive sign and significant in all specifications as it was in the first model. Per capital also have the same positive sign and it is significant. CPI has included in three specifications and it has a negative sign in all three specifications but it is significant only in one speciation. Population growth is included in two specifications; it has a positive sign but it is not significant in one specification.

5. CONCLUSION

The present study seeks to disentangle the influence of corruption on inward FDI. Sample of developing Asian economies is used for the empirical investigation for the period 2000 to 2017. System GMM technique is carried out to find out the results. The results validate the grease the wheel hypothesis of corruption, indicating that corruption act as grease money in the presence of a weak regulatory framework for the panel of developing economies. In the model of FDI other control variables are Gross Fixed Capital Formation (GFCF), Trade Openness (TO), Inflation, Population (POP) and Per Capita GDP. All the explanatory variables have expected signs. GDP, GFCF, TO, Population, and per capita GDP positively affect the FDI inflows. However, the inflation rate in the host economy discourages the inward FDI.

Based on the findings of the present study it is concluded that corruption is not deterrence for inward FDI for the case of developing Asia therefore following policy recommendations can be suggested.

- Corruption is not deterrence for inward FDI, so resources should be devoted to other important determinants of inward FDI along with anti-corruption policies.

- Trade openness has a positive impact on inward FDI; Govt. should adopt policies to improve the economic openness of a country.

- Inflation as a measure of macroeconomic stability harms inward FDI. Tools of monetary policy should be used more effectively to control the inflation rate since more inflation creates uncertainty about the future returns of investment.

- GFCF as indicators of domestic investment also encourage foreign investor. 
Policies should be formulated to encourage domestic investor. Ease of doing business should be enhanced through proper policy formation for domestic investor and foreign investor as well.

- Population variable is found a positive and significant determinant for inward FDI. Policies should be developed to make this population more educated and skilled. The focus should be on skills and technical education. This can enhance the productivity of the labor input.

\section{REFERENCES}

Alemu, A. M. (2012). Effects of corruption on FDI inflow in Asian economies. Seoul Journal of Economics, 25(4), 387-412.

Al-Sadig, A. (2009). The effects of corruption on FDI inflows. Cato Journal, 29(2), 267294.

Ardiyanto, F. (2012). Foreign Direct Investment and Corruption (Unpublished doctoral dissertation) Colorado State University, Fort Collins, Colorado.

Arellano, M., \& Bover, O. (1995). Another look at the instrumental variable estimation of error-components models. Journal of Econometrics, 68(1), 29-51.

Azam, M., and Ahmad, S. A., (2013). The Effects of Corruption on Foreign Direct Investment Inflows: Some Empirical Evidence from Less Developed Countries. Journal of Applied Sciences Research, 9(6), 3462-3467, 2013 ISSN 1819-544X.

Barassi, M. R., \& Zhou, Y. (2012). The effect of corruption on FDI: A parametric and nonparametric analysis. European Journal of Political Economy, 28(3), 302-312.

Bayraktar, N. (2015). Importance of Investment Climates for Inflows of Foreign Direct Investment in Developing Countries. Business and Economic Research, 5(1), 2450.

Beck, P. J., \& Maher, M. W. (1986). A comparison of bribery and bidding in thin markets. Economics Letters, 20(1), 1-5.

Bellos, S., \& Subasat, T. (2012). Corruption and foreign direct investment: A panel gravity model approach. Bulletin of Economic Research, 64(4), 565-574.

Bjorvatn, K., \& Søreide, T. (2005). Corruption and privatization. European Journal of Political Economy, 21(4), 903-914.

Blundell, R., and Bond, S., (1998). Initial conditions and moment restrictions in dynamic panel data models. Journal of Econometrics, 87, 115-143.

Brouthers, L. E., Gao, Y., \& McNicol, J. P. (2008). Corruption and market attractiveness influences on different types of FDI. Strategic Management Journal, 29(6), 673680.

Cai, H., Fang, H., \& Xu, L. C. (2011). Eat, drink, firms, government: An investigation of corruption from the entertainment and travel costs of Chinese firms. The Journal of Law and Economics, 54(1), 55-78.

Dollar, D., \& Kraay, A. (2004). Trade, growth, and poverty. The Economic Journal, 114(493), F22-F49.

Drabek, Z., \& Payne, W. (2002). The impact of transparency on foreign direct investment. Journal of Economic Integration, 17(4), 777-810. 
Egger, P., \& Winner, H. (2005). Evidence on corruption as an incentive for foreign direct investment. European Journal of Political Economy, 21(4), 932-952.

Egger, P., and Winner, H., (2006). How corruption influences foreign direct investment: a panel data study. Economic Development and Cultural Change, 54(2), 459-486.

Fisman, R., \& Svensson, J. (2007). Are corruption and taxation really harmful to growth? Firm level evidence. Journal of development economics, 83(1), 63-75.

Godinez, J. R., \& Liu, L. (2015). Corruption distance and FDI flows into Latin America. International Business Review, 24(1), 33-42.

Habib, M., \& Zurawicki, L. (2002). Corruption and foreign direct investment. Journal of International Business Studies, 33(2), 291-307.

Hakkala, K. N., Norbäck, P. J., \& Svaleryd, H. (2008). Asymmetric effects of corruption on FDI: evidence from Swedish multinational firms. The Review of Economics and Statistics, 90(4), 627-642.

Hellman, J. S., Jones, G., \& Kaufmann, D. (2003). Seize the state, seize the day: state capture and influence in transition economies. Journal of Comparative Economics, 31(4), 751-773.

Hines J. R. (1995). Forbidden payment: Foreign bribery and American business after 1977. NBER working paper No. 5266. Harvard University, USA: National Bureau of Economic Research. (DOI): 10.3386/w5266.

Huntington, S. P., (1968). Political Order in Changing Societies. New Haven: Yale.

Janicki, H. P., \& Wunnava, P. V. (2004). Determinants of foreign direct investment: empirical evidence from EU accession candidates. Applied Economics, 36(5), 505-509.

Judge, W. Q., McNatt, D. B., \& Xu, W. (2011). The antecedents and effects of national corruption: A meta-analysis. Journal of World Business, 46(1), 93-103.

Kolnes, V. L. (2016). Foreign Direct Investment and Corruption: An Econometric Analysis of the Multidimensional Effects of Corruption upon FDI Inflow (Unpublished graduate thesis in Comparative Politics). University of Bergen, Norway. http://hdl.handle.net/1956/12818

Leff, N. H. (1964). Economic development through bureaucratic corruption. American Behavioral Scientist, 8(3), 8-14.

.Leys, C. (1965). What is the Problem about Corruption? The Journal of Modern African Studies, 3(2), 215-230.

Lui, F. T., (1985). An equilibrium queuing model of bribery. Journal of Political Economy, 93(4), 760- 81.

Mauro, P. (1995). Corruption and Growth. The Quarterly Journal of Economics, 110(3), 681-712. Retrieved March 1, 2021, from http://www.jstor.org/stable/2946696.

Navickas, V., Navickas, M., \& Kordoš, M. (2016). Corruption effect on foreign direct investments in European Union countries. Business: Theory and Practice, 17(4), 299-306.

Nye, J. S. (1967). Corruption and political development: A cost-benefit analysis. American Political Science Review, 61(2), 417-427.

Ohlsson, M. H. (2007). Impact of corruption on FDI: A Cross-Country Analysis (Unpublished doctoral dissertation) Jönköping International Business School, Jönköping University, Sweden.

Omodero, C. O. (2019). Effect of corruption on foreign direct investment inflows in Nigeria. Studia Universitatis „Vasile Goldis” Arad-Economics Series, 29(2), 5466.

Pajunen, K. (2008). Institutions and inflows of foreign direct investment: A fuzzy-set 
analysis. Journal of International Business Studies, 39(4), 652-669.

Petrou, A. P., \& Thanos, I. C. (2014). The "grabbing hand" or the "helping hand" view of corruption: Evidence from bank foreign market entries. Journal of World Business, 49(3): 444-454.

Quazi, R. M. (2014). Corruption and foreign direct investment in East Asia and South Asia: An econometric study. International Journal of Economics and Financial Issues, 4(2), 231-242.

Quazi, R., Vemuri, V., \& Soliman, M. (2014). Impact of corruption on foreign direct investment in Africa. International Business Research, 7(4), 1.

Ravi, S. P. (2015). Does corruption in a country affect the foreign direct investment? a study of rising economic super powers China and India. Open Journal of Social Sciences, 3(07), 99-104.

Rose-Ackerman, S. (1997). The political economy of corruption. Corruption and the global economy, 31, 60.

Saha, B. (2003). Harassment, corruption and tax policy: a comment on Marjit, Mukherjee and Mukherjee. European Journal of Political Economy, 19(4), 893-897.

Smarzynska, B. K., \& Wei, S. J. (2000). Corruption and composition of foreign direct investment: Firm-level evidence. NBER Working Papers 7969, National

Tanzi, V., \& Davoodi, H. R. (2000). Corruption, Growth and Public Finances (IMF Working Paper, WP/00/182, 24).

Udenze, O. (2014). The effect of corruption on foreign direct investments in developing countries. The Park Place Economist, 22(1), 87-95. https://digitalcommons.iwu.edu/parkplace/vol22/iss1/17.

United Nations Conference on Trade and Development (2015). World Investment Report (2015). New York and Geneva, United Nations

United Nations Conference on Trade and Development (2016). World Investment Report (2016). New York and Geneva, United Nations

United Nations Conference on Trade and Development (2017). World Investment Report (2017). New York and Geneva, United Nations

Voyer, P. A., \& Beamish, P. W. (2004). The effect of corruption on Japanese foreign direct investment. Journal of Business Ethics, 50(3), 211-224.

Wah, S. H., (2009). Is Corruption Endogenous to Foreign Direct Investment in ResourceRich Developing Economies? (Graduate Theses and Dissertations. 11015), lowa State University, United States. https://doi.org/10.31274/etd-180810-1125

Wei, S. J., \& Wu, Y. (2002). Negative alchemy? Corruption, composition of capital flows, and currency crises. In Preventing currency crises in emerging markets (pp. 461506). University of Chicago Press.

Wei, S. J. (2000). How taxing is corruption on international investors? Review of Economics and Statistics, 82(1), 1-11.

Xu, G., Zhang, D., \& Yano, G. (2017). Can corruption really function as "protection money" and "grease money"? Evidence from Chinese firms. Economic Systems, 41(4), 622-638.

Zhao, J. H., Kim, S. H., \& Du, J. (2003). The impact of corruption and transparency on foreign direct investment: An empirical analysis. Management International Review, 43(1), 41. 